\title{
A MEMÓRIA INTRAGERACIONAL E A MEMÓRIA COMPARTILHADA SOBRE AS EXPERIÊNCIAS TRANSMITIDAS ENTRE AVÓS E NETOS EM TEUTÔNIA (RS) ${ }^{1}$
}

\author{
Maria Cristina Caminha de Castilhos França*
}

\section{Resumo}

Estudo de antropologia sobre a memória intrageracional e compartilhada na cidade de Teutônia. Trata-se de uma pesquisa etnográfica (2000-2001) realizada junto a antigos moradores, descendentes dos imigrantes alemães, que colonizaram esta região que hoje é uma cidade próspera localizada no Vale do Taquari (RS). Investiga-se, a partir de narrativas biográficas, as tradições transmitidas de geração a geração na vida cotidiana, pelo qual os avós socializam seus filhos e netos à tradição de seu ethos de pertencimento enraizado em uma trajetória de descendência alemã, bem como ressituam estes valores no tempo presente reordenandoos sob a luz das novas condições socioculturais advindas das transformações decorrentes da modernidade.

Palavras-chave: Memória. Cidade. Etnia. Gerações. Narrativas. Comunidade teuto-brasileira.

\section{Introdução}

O propósito deste artigo é reconhecer a importância da relação intrageracional compartilhada para a reconfiguração dos traços culturais parcialmente distintos que traz, por intermédio da figura dos avós, a tradição de uma sociedade agrícola luterana alterada pelo processo de modernização e, por outro lado, novas definições de espaço e tempo, vivenciadas com plenitude pelos netos.

\footnotetext{
Esse trabalho é uma versão da dissertação de Mestrado, apresentada ao Programa de PósGraduação em Antropologia Social da Universidade Federal do Rio Grande do Sul (UFRGS), Porto Alegre, em fevereiro de 2002.

Mestre em Antropologia Social pela Universidade Federal do Rio Grande do Sul. E-mail: mcristinaf@terra.com.br
} 
Esse artigo é resultado de uma pesquisa antropológica realizada entre 2000 e 2001, junto a antigos moradores descendentes dos imigrantes alemães, que colonizaram a região que hoje é formada por próspera cidade localizada no Vale do Taquari, distante 100 quilômetros da capital do Rio Grande do Sul. A investigação deu-se a partir de um exercício em que se buscou desenvolver narrativas biográficas dos antigos moradores e, em alguns casos, a convivência estendeu-se aos familiares do indivíduo ou casal da rede formada ${ }^{2}$.

A pesquisa teve como intencionalidade tratar da memória dos habitantes de Teutônia sobre sua cidade e sua comunidade, a partir da relação trans e intergeracional. Com base nisso, desenvolveu-se uma relação, pelo menos, com três gerações teutonienses, descendentes dos imigrantes alemães que fundaram a cidade. Foi privilegiado o ponto de vista da geração mais velha para conhecer, a partir de seus testemunhos, o processo de construção desse núcleo populacional, hoje cidade. Para tanto, partiu-se das seguintes questões antropológicas: Quem são os teutonienses? Como pensam? Como vivem? Como se organizam e interagem? Quais seus conflitos e contradições? Quais são suas referências ao passado e seus projetos futuros?

\footnotetext{
2 A rede de informantes foi constituída, inicialmente, por meio de uma relação de parentesco que a pesquisadora mantém com a localidade - fato esse de grande influência na escolha do universo de pesquisa - e, mais adiante, contou-se com o auxílio do Museu Municipal. O universo pesquisado compreendeu indivíduos idosos, moradores do município de Teutônia. Foram realizadas 25 entrevistas abertas com esses indivíduos, sendo que com cinco deles houve um acompanhamento mais intenso em que suas famílias foram envolvidas. Por meio delas buscou-se analisar o processo de construção social da identidade desses indivíduos que almejam, com constância, definir-se como sujeitos em um universo de profundas alterações, cujo ritmo alucinante desafia a permanência de valores e representações sobre o experienciado, em um contexto de comprometida ligação ao passado. A adoção de relatos biográficos, além de buscar um material rico para a análise do vivido e o reflexo da dimensão coletiva a partir da visão individual, é bastante elucidativa em estudos que envolvem grupos de indivíduos idosos, em que a evocação de um tempo passado se dá com maior ênfase. Ou seja, a relação entre a idade cronológica - percebida como etapa última da vida - e a linguagem como veículo de "socialização das lembranças" (FERREIRA, 2000) permite estabelecer as várias temporalidades que cruzam o sujeito, uma vez que ele dispõe de mais tempo para atividades reflexivas em substituição às atividades que se referem ao trabalho. A aproximação obtida junto a esses grupos baseou-se na observação participante de um cotidiano de convivência com a geração entrevistada, em que os fenômenos observados forneceram ricas informações sobre a realidade dos atores sociais em seus próprios contextos. Os eventos observados no dia-a-dia aconteceram tanto nas unidades residenciais dos entrevistados, como em espaços públicos como: igreja, baile ou restaurante. Em alguns casos, filhos e netos participaram de alguns momentos em que os avós narravam suas lembranças.
} 
A partir de uma memória compartilhada entre diferentes gerações, sobretudo entre avós e netos, buscou-se conhecer, nas suas práticas e representações, as tradições transmitidas de geração a geração da vida cotidiana, pelas quais os avós socializam seus filhos e netos à tradição de seu ethos de pertencimento enraizado em uma trajetória de descendência alemã. Nesse sentido, buscou-se investigar como essas gerações ressituam esses valores no tempo presente e os reordenam sob a luz de novas condições socioculturais advindas das transformações decorrentes da modernidade.

As noções de memória transgeracional (HALBWACHS, 1990) e memória compartilhada (RICOEUR, 2000) investigadas por meio da etnografia da fala permitiram reconhecer, na interação dos avós e netos, não só os conteúdos transmitidos e as experiências narradas, como também os hábitos compartilhados. Foram investigados os referenciais específicos de organização do tempo coletivo apoiados na memória da cidade em confronto com as novas definiç̧ões de espaço e tempo herdadas com o advento da modernidade. Esses aspectos conflitivos são ressignificados positivamente na interação das gerações, envolvidos pela ordem do afeto. Foi por meio do mapeamento dos traços culturais reconfigurados na relação entre avós e netos e das formas singulares de organizar e reordenar o tempo através da memória compartilhada, que foi estruturado esse estudo.

Nesse sentido, a condição de avós é essencial para reconhecer a existência de uma relação recíproca, em que avós e netos se reconstituem e se renovam como sujeitos no interior do cotidiano prático e simbólico por eles vivido e partilhado em uma cidade do interior. A ação de contar histórias vividas reinventando a dramática no cotidiano é uma forma de troca de experiência em que esses sujeitos se nutrem ora da cultura oral, ora da vertente simbólica dos rastros.

\section{A Comunidade Teutoniense: construção social da identidade teuto- brasileira}

Teutônia é uma cidade com características interioranas. Por um lado traz as características de um contexto urbano devido à sua estrutura econômica, política e administrativa, por outro lado, mantém fortemente as características de uma vida ritmada pela sociabilidade de interior, onde se colocam de forma mais intensa as relações intergeracionais, familiares, de vizinhança, de bairro, religiosas e associativas e onde pessoas e redes se cruzam, 
conformando um território de pertencimento e de identidade no cotidiano, em que uma memória coletiva é tecida.

Os entrevistados pertencem a uma camada média em termos socioeconômicos, cujo poder aquisitivo tem origem na produção agrícola. Esse grupo mostra-se homogêneo, também, no que diz respeito à religiosidade herdada de seus ascendentes, o luteranismo. As trajetórias sociais, portanto, mantêm-se semelhantes diante de uma comunidade que foi construída com base nos fortes traços de uma tradição de origem germânica ${ }^{3}$. Já seus netos e bisnetos, diante da convivência com novos grupos de origens distintas que passaram a habitar a região dentro de um processo de urbanização e industrialização, construíram diacronicamente as representações sobre germanidade. Além disso, a própria demanda de funções ligadas ao trabalho que exige mão-de-obra especializada e as novas oportunidades de atuação no cenário das forças de trabalho voltadas para o interesse das indústrias fizeram com que as gerações seguintes buscassem novos rumos, incluindo o projeto de formação escolar e a busca de moradia em outros municípios que oferecem maior gama de possibilidades de instrução e de trabalho melhor remunerado ${ }^{4}$.

Tem-se, portanto, Teutônia ${ }^{5}$, constituída como colônia alemã, onde seus colonizadores mantinham diferenças culturais específicas, entre elas os

${ }^{3}$ Ao falar-se em imigrantes da Alemanha, antes de 1871, ano da unificação, refere-se às pessoas de fala alemã - diferentes dialetos com um tronco lingüístico de origem, conforme Lang (1995).

4 A história do município de Teutônia relaciona-se à imigração alemã, que iniciou no Brasil, na então Província do Rio Grande de São Pedro, a partir de 1824, com a criação da Colônia Alemã de São Leopoldo. Os núcleos brasileiros de colonização eram determinados, inicialmente, pelo governo imperial. As primeiras levas de colonos, oriundos do território do Hunsrück, região das montanhas entre o Reno e o Mosela, foram estabelecidas no Vale do Rio dos Sinos, mais precisamente, na Real Feitoria do Linho-Cânhamo. Em meados do século XIX o Vale do Rio dos Sinos apresentava-se bastante populoso; as terras disponíveis já estavam nas mãos dos imigrantes alemães e seus descendentes nascidos no Brasil. À proporção que novos imigrantes chegavam, ou mesmo os descendentes passavam a constituir família e necessitavam de terras próprias para desenvolver, empresas colonizadoras de capital privado encarregavam-se de comercializar terras devolutas. Foi o caso de terras no Vale do Taquari e, em específico a então Colônia de Teutônia, que passou a ser habitada a partir de 1858. Entre 1868 e 1878, as terras que constituíam as picadas do centro-norte da Colônia foram ocupadas por imigrantes westfalianos, vindos direto da Westfália (Confederação Germânica) para o Vale do Taquari.

5 “A denominação de Teutônia seria uma referência às tribos bárbaras dos teutões, que tinham sido moradores das margens do Mar Báltico e de muita influência na formação do povo alemão. Seria em nível do Rio Grande do Sul, uma referência ao empreendimento de germânicos, que praticamente dominaram na ocupação do território em questão.” (LANG, 1995, p. 14). 
dialetos diferentes: ao sul falava-se o dialeto do Hunsrück, enquanto ao norte falava-se o dialeto sapato de pau $^{6}$. O que havia em comum, e que se manteve em certa homogeneidade até a década de 1970, é a religião evangélica luterana.

Pode-se sugerir que o processo de colonização desses imigrantes se constituiu em uma dramática cotidiana de pioneirismo ritmado pelo valor trabalho, próprio do ethos cultural alemão na sua luta por vencer os obstáculos para a realização do projeto de aquisição de terra, de produtividade da terra e de construção de uma comunidade disposta aos ideais prometéicos.

Observa-se, inicialmente, um período em que a fase de ocupação e plantio em condições precárias foi bastante difícil para os pioneiros - as primeiras obras erguidas pelos colonos foram os cemitérios em vista dos falecimentos rotineiros ocasionados por acidentes de trabalho e falta de recursos médicos. Também, houve um esforço em erguer escolas e igrejas, com o intuito de promover uma sociabilidade cultural importante, contando com os recursos da comunidade.

No período da II Guerra Mundial, já se tem, no território brasileiro, mais de cem anos de presença de colonização alemã. Ainda que os descendentes de imigrantes estivessem à margem da cidadania, apesar de terem sido assegurados os direitos civis do jus soli , " "[ . . . ] as colônias alemãs não podiam ser consideradas assimiladas, mas paulatinamente o processo de urbanização e industrialização ia tornando-as teuto-brasileiras." (SEYFERTH, 1994, p. 16).

O contato com outras comunidades intensifica a reafirmação de uma identidade étnica, em que o uso cotidiano da língua alemã é o elemento de distinção preferencial. Junto a esse elemento unem-se outros como as instituições formais da comunidade, associações e escolas, a celebração de datas, como a da unificação da Alemanha, e o estímulo às atividades folclóricas (corais, grupos de dança). Todavia, segundo Seyferth (1994, p. 17), "[ . . ] a idéia de uma ligação nacional com a Alemanha se baseia no direito de sangue e se naturaliza através da língua".

Percebem-se, dessa forma, os dois princípios delimitadores da identidade teuto-brasileira: por um lado, a origem étnica alemã vinculada ao direito de sangue, por outro lado, a nacionalidade/cidadania brasileira, com seu princípio territorial. Para Seyferth:

${ }^{6}$ Foram mantidas as denominações dos dialetos em idiomas diferentes, conforme o uso corrente dos informantes.

7 “O fundamento da cidadania no Brasil é o jus soli, que assegura o pertencimento ao Estado para filhos de imigrantes nascidos no país." (SEYFERTH, 2000, p. 144) 


\begin{abstract}
A noção de germanidade, nesse sentido, produziu a identidade étnica definida por princípios primordialistas de vinculação nacional, baseados objetivamente numa 'cultura comum' e num processo histórico compartilhado de imigração e colonização. (SEYFERTH, 2000, p. 168).
\end{abstract}

\title{
3 A Comunidade Atual
}

É importante reconhecer as mudanças compreendidas nas trajetórias de vida na relação com a cidade, a partir das lembranças e reminiscências dos entrevistados, para conhecer, nas suas representações, os significados culturais dos novos tempos.

As trajetórias e os papéis complexos são assinalados nas biografias de modo a perceber relações como tradicional e moderno, holismo e individualismo, religiosidade e conhecimento, como constituidoras de identidades individuais e de confrontos geracionais acompanhados de toda a dramática que isso acarreta.

Com isso, são reconhecidas, na comunidade idosa teutoniense, constantes negociações sociais reveladoras das singularidades étnicas herdadas da condição formativa de colonos que viviam no meio rural, condição definida por seus membros a partir do uso cotidiano da língua alemã e da preservação de usos e costumes alemães, como hábitos alimentares, organização do espaço doméstico, formas de sociabilidade e comportamento religioso.

Essas constantes negociações sociais, além de revelarem a etnicidade, elucidam o quanto a interação com as gerações dos filhos, mas principalmente dos netos, que vivem um outro período histórico-político da cidade e remetem a novas condições de organização moderna de vida cotidiana e novas configurações de valores, recria um novo sistema de significações cujo processo de dinamização está na transmissão e no compartilhamento da memória dos avós sobre um passado e um presente vividos nas interações cotidianas da família, nas relações de vizinhança e nos processos de sociabilidade.

O ideal social conformado a partir de traços significativos percebidos nos colonos, como o empenho no trabalho, a vocação empreendedora e a religiosidade, é um projeto concretizado no desenvolvimento acelerado das regiões por eles ocupadas. Aos poucos foram surgindo pequenos comércios nas picadas e linhas, contendo os materiais mais variados que oportunizavam 
maior conforto à comunidade. Esses comércios se estabeleciam próximos à igreja, à escola e ao cemitério da localidade. Os núcleos habitados pelas levas de colonos que vieram durante os três períodos de ocupação da Colônia de Teutônia foram aos poucos dando forma a pequenos bairros que, à medida que se desenvolvia a comunidade, geravam uma maior autonomia desses núcleos.

O hábito de solidarizar-se com os seus vizinhos e parentes foi o que propiciou a formação de cooperativas que concentravam a produção e a vendiam com maior poder de barganha.

$\mathrm{O}$ excedente produzido passou, assim, a gerar maior lucratividade e interação com outros pólos comerciais. A partir desse sucesso empreendedor e com o reconhecimento de que estava fortificada financeiramente e se encontrava participando do cenário político do município de Estrela, a Colônia de Teutônia emancipou-se em 1981. A habilidade administrativa levou essa localidade rapidamente à condição de uma das maiores economias do Vale do Taquari. O processo de modernização avançou aceleradamente, dando uma nova ética e estética ao local.

\subsection{Novos Tempos na Comunidade de Teutônia}

O perfil dos habitantes dos municípios de Teutônia vem alterando-se gradativamente desde a década de 30 quando, por meio da campanha de nacionalização ${ }^{8}$, as colônias teuto-brasileiras passaram a participar com mais intensidade do cenário sóciopolítico do país.

Detentores de uma economia agrária muito bem-estruturada em torno de pequenas cooperativas, os colonos mantinham reservas monetárias acumuladas ao longo de muitos anos de trabalho. A adoção de empréstimos a empresários principiantes da indústria artesanal com juros previamente combinados tornou-se a tônica da época. Retendo divisas monetárias consideráveis com base nos lucros desses empréstimos, os colonos passaram a edificar grandes residências e a adquirir novos lotes de terras para ampliar suas atividades baseadas na criação de porcos e galinhas e na produção de leite, nata, ovos.

Parte desses recursos destinava-se às despesas de sobrevivência dentro da cultura germânica de poupar o excedente, aproveitar ao máximo o uso de bens e manter o trabalho familiar de forma exaustiva. Com base nesses

${ }^{8}$ Campanha promovida pelo governo federal, em 1938. 
princípios, a carestia dos ancestrais, passada na Europa, foi sendo deixada para trás, e o presente, caracterizado pela abundância, previa o futuro com a ação de poupar.

Mantenedores do sentido comunitário, o trabalho em mutirão possibilitou expandir a rede elétrica iniciada na década de 30 com a instalação do primeiro gerador movido por força hidráulica em uma propriedade particular. No final da década de 50, por um acordo político, a rede elétrica foi ligada à Companhia Estadual de Energia Elétrica (CEEE), ainda responsável pela distribuição de energia elétrica no Estado do Rio Grande do Sul.

A partir da regularização da eletrificação na região, as pequenas cooperativas uniram-se para fundar a Cooperativa Languiru. A manutenção e a ampliação do sistema energético possibilitou a instalação de novas indústrias e empresas, incluindo a indústria de laticínios com recursos da Cooperativa Languiru, como testemunha August: "O melhoramento do sistema elétrico possibilitou a expansão e a criação de outras empresas, além da de laticínios. Foi um fator fundamental para Languiru (bairro) e para a região. Logo a seguir foi construída a primeira rede de distribuição de água. A zona rural demorou mais a participar das vantagens da eletrificação, pois não entendiam muito a necessidade das quotas para as cooperativas de eletricidade e água. " (informação verbal).

O advento da luz elétrica trouxe progressivas mudanças de hábitos, introdução e adaptação a novos valores familiares. A partir dos anos 60 a comunidade passou a investir em bens de consumo, o que, aliado ao custeio mensal de taxas de iluminação e outros impostos, gerou certas dependências financeiras. Com o aumento substancial dos recursos para o consumo familiar, o excedente poupado passou a ser consumido em virtude de novos princípios que o processo de modernização trouxe à comunidade.

Nesse sentido, a partir da estreita relação com novos modelos e valores citadinos adquiridos por meio dos veículos de comunicação e dos estudos que passaram a realizar fora das fronteiras da região de colonização alemã na capital do Estado ou em centros maiores do interior, como Caxias do Sul, São Leopoldo e Lajeado - as novas gerações trouxeram novos ritmos à tradicional convivência familiar e comunal.

A interação com a vizinhança por intermédio de visitas mútuas às residências e de encontros em eventos patrocinados pela igreja ou por centros culturais e lúdicos (corais, clubes de bolão, clubes de tiro, festas), onde os 
laços de amizade eram reforçados, conhece uma nova realidade pela adoção do consumo da televisão e da comunicação por telefone, que marca novos ritmos à interação social.

As famílias circunvizinhas passaram a organizar-se sob novas temporalidades, no ritmo de uma sociedade que se modernizava. Esses novos ritmos são pensados pela comunidade sob o viés da continuidade do passado, pela reordenação das experiências que trazem novos significados e lhes direcionam o futuro?.

Nesse novo contorno social, em que a conquista de um lugar seguro no contexto nacional mostrou-se transformada pelas novas exigências do novo tempo - tanto no que diz respeito à atuação como cidadão brasileiro oriundo de uma sociedade teuto-brasileira, como a de cidadão que auxiliou, com o seu trabalho, a deixar para trás, deixar apenas como experiência vivida, a miséria e a carestia que seus ancestrais detinham quando aqui chegaram.

\subsection{O Novo Tempo, o Tempo dos Netos}

O processo de individualização na geração dos netos assume contornos bastante diferenciados daqueles vividos pelos avós em relação à convivência que esses tiveram com seus avós. A coabitação das gerações mais velhas com as mais jovens não é mais um fenômeno recorrente como o que existia no período que os avós viviam a infância em Teutônia.

Outro aspecto importante que interfere na alteração das formas de trocas intergeracionais é o papel da socialização escolar, que passou por uma reformulação de considerável dimensão em relação às escolas freqüentadas pelos avós: o espaço escolar mantinha-se restrito à comunidade e exercia a função de reproduzir os emblemas que definiriam o ethos alemão e que eram acionados pela comunidade como marca de pertencimento, como sugere a entrevista de Johan: " A escola era comunitária, era algo assim de estudar muito e cada criança tinha que ir pra escola.Os meninos estudavam cinco anos e as meninas quatro anos. As meninas saíam da escola um ano antes para a confirmação. Aqui todos são evangélicos e as meninas eram confirmadas um ano antes. Eu me lembro que meu pai dizia assim: 'As meninas têm que estudar só quatro anos e os meninos têm que estudar um pouco mais'. Costume, né? E lá por 1920, o Ritzel

9 Conforme sugere Eckert: "Viver hoje é igualmente guardar uma ligação do passado, emprestando sentido aos valores e às práticas coletivas e individuais no presente.” (1993, p. 15). 
lá da Linha Germano, ele numa assembléia disse: 'Nós estamos no Brasil, nós temos que ensinar também o português pras nossas crianças, embora eu não sei falar, mas nós temos que ensinar às nossas crianças a língua portuguesa." "' (informação verbal).

Nesse sentido, no período em que a campanha de nacionalização foi instaurada, permanecia a carência de recursos humanos que dessem conta da nova exigência, conforme relata Reinhold: "Estudei só o primário, era uma escola de quatro paredes, bem simples. Mas só se falava alemão. Eu aprendi a estudar português no quarto ano, era junto com o professor, ele também não sabia direito o português. Você nem imagina a dificuldade que nós tivemos quando foi proibido o alemão. O professor uma vez foi preso por causa disso, porque ele falou com os alunos em alemão e foi pego em flagrante, então dali em diante simplesmente ou não falava ou falava em português. A moradia dele era do lado, e quando dava o recreio ele foi pra casa, abriu a janela e gritou lá de dentro: 'Falar português, na ordem!'. A gente pegava a merenda, eu sentava no banco e ficava quieto, não sabia falar, nem eu nem os outros." (informação verbal).

Hoje, a escola institucionalizada, com base em um currículo unificado a partir de programas educacionais de âmbito nacional, acena para uma territorialização cultural em que os novos traços identitários atualizam a comunidade de pertencimento, as redes, as ancestralidades, as fronteiras culturais, que se alargaram, o ethos alemão, que se hibridizou, e a incorporação das contradições do mundo moderno que se estabeleceu.

O processo de modernização e a proximidade com a sociedade brasileira mais ampla provocaram alterações nos signos de identidade, acionando a emergência de fenômenos que recriaram novos atributos para redefinir os espaços objetivos de reivindicação. Teutônia, atualmente, conta com escolas de Ensino Médio, bem como com uma escola técnico-agrícola. As rodovias municipais e intermunicipais asfaltadas e o acesso a um transporte coletivo rodoviário eficiente trouxeram a Teutônia proximidade a municípios com maiores recursos, com universidades, oportunidades de trabalho mais qualificado e lazer diversificado.

A adoção de projetos pessoais, em geral em concordância com os projetos familiares que envolvem a internalização dos valores da sociedade moderna, acena na direção de uma trajetória de ascensão social que passa pela conquista de um diploma universitário ou de um cargo de prestígio no 
seio da comunidade que assegure uma carreira profissional estável. A religião, como demarcadora de fronteiras simbólicas no interior desse universo, também se apresenta em processo de mudança ao se observar práticas mais flexíveis, diferentes das práticas religiosas conservadoras transmitidas pelos avós. A confirmação luterana é realizada por todos, no entanto o comparecimento aos cultos semanais não é compartilhado pelos netos com o mesmo rigor.

Segundo Edmund, um fenômeno delimitador da modernidade é a tecnologia, tendo a televisão como a principal responsável pela diminuição de valores importantes para a coesão social: "E a televisão, até os desenhos animados só tem violência! Mas o quê? Não conta mais as historinhas da Branca de Neve, da Cinderela! Só tem violência. Aqueles homens terriveis das cavernas... Acho primeiro, deviam servir de base naquele tempo quando saímos do alemão e entramos no português, os primeiros livros de literatura falavam do velho Ângelo. 'O velho Ângelo andava com aquelas bolsas, levava sua mercadoria pra cidade no lomba do burrinho, e ai foi assaltado e foi morto por assaltantes, que ai o assaltante pegou o dinheiro dele e foi lá pra cidade e foi tomar as cervejadas dele e se meteu numa briga e foi morto também. Então a moral da história: quem com ferro fere, com ferro será vencido'. Isso foi as primeiras lições que nós levamos, né? Então, nesse sentido, tem que educar sempre direcionando pra praticar o bem e nunca o mal. É complicado, né? Não sei fazer melhor, mas sei viver.[ . . . ] A tecnologia tá trazendo coisas maravilhosas, mas elas deviam ser melhor aproveitadas, melhor usadas, porque não vai ser possível denunciar toda uma humanidade em função de toda vida, onde a pessoa não aprenda a repartir com os outros, então só se conseguissem daqui pra frente educar as crianças a respeitaremo próximo, não roubarem, repartir com todo mundo. As leis de Deus, os dez mandamentos e não precisavam ter outras leis." (informação verbal).

A vida no município de Teutônia surge, então, sob a visão de novos estilos de vida decorrentes das relações de associação ou dissociação no sistema de estratificação ${ }^{10}$.

Ou seja, houve uma drástica alteração nos contornos desse grupo social, em que o abandono gradual do cenário rural para a instância urbana trouxe a adoção de outras ordens que conferiram novos estatutos de relação

\footnotetext{
${ }^{10}$ A concepção weberiana de sistema de estratificação comporta a existência de grupos de status como comunidade de indivíduos que partilham do mesmo "estilo de vida" e interagem como iguais em termos de status.
} 
interna. Essas ordens englobam a atuação nas instituições com bases industrial, comercial, financeira e burocrática.

Logo, as formas de consumo e a adoção de novos ritmos contribuem, seguindo o que trata Bourdieu (1979), para o reconhecimento dos significados atribuídos pelos grupos às suas ações e da própria imagem social do grupo.

Nesse sentido, duas questões são, aqui, fundamentais para se tratar da transmissão de experiências de um passado vivido pela interpretação da memória dos ancestrais: o tempo contínuo do grupo social e o tempo descontínuo do indivíduo, em que se estabelece a noção de duração enquanto experiência vivenciada individual e coletivamente por meio da cultura do grupo investigado.

Ao longo das entrevistas, ao refletirem sobre a relação com os seus netos, alguns avós assinalavam que, hoje, essa é uma realidade com dificuldades e insatisfações, pelo convívio irregular com os netos devido à distância geográfica ou à falta de hábito de dialogar com mais vagar com essa geração; ou então apontavam a falta de interesse dos netos em dialogar com os avós e ouvi-los em suas lembranças e opiniões. É interessante definir que a descrença está centrada especificamente na ação de contar histórias. Helen atribui aos novos tempos, aos tempos dos netos, a ruptura da troca, da experiência compartilhada.

Observa-se, também, que a distância e a falta de convivência sistemática compõem outro fator complicador na manutenção do diálogo e da autoridade para dar conselhos. Ao ser abordada sobre o que narrava a seus netos, Frieda relata em tom de pesar: "Conto poucas histórias aos meus netos, muito pouco, porque eu muito pouco tenho contato. Eu vou às vezes lá [municípios do interior do Estado e capital, Porto Alegre], mas assim... o pequeno da Elise [filha], que é professora de música, esse eu cuidei bastante, porque o marido já era falecido, aí eu fiquei uns 14 dias lá com ela, depois eu ia bastante lá. Mas os outros, assim, a gente só ia um fim de semana e voltava, mas eu sempre tento quando eu vou dizer pra eles como se comportar, e pra ser, como eu acho que eles devem levar a vida.[...] Depois que eu fiquei viúva eu não vou muito, porque eles estão trabalhando, todo o tempo trabalhando, né? Mas eu converso com todos, todos me respeitam." (informação verbal).

A ausência dos familiares por perto e os esparsos encontros, que se restringem às festas de Natal ou aniversário, trazem um sofrimento velado do qual Frieda busca convencer-se de que não passa de circunstância que a 
vida lhe atribuiu. Nesse sentido, tomar consciência de que a privação da convivência familiar é revelada como sofrimento foi uma experiência pessoal nada confortável. Entretanto, a presença de seus entes, de seus afetos, está por todos os cantos da casa: seja em fotografias, seja em objetos que lhe pertenceram na infância ou que lhe foram presenteados.

Entrevistar Hermine, que sofreu a perda recente do marido, trouxe instantes de emoção e gravidade. Ela não fala português, vive sozinha em uma casa imensa malconservada; a exigüidade de recursos financeiros (quase toda a sua aposentadoria é comprometida com medicamentos) e a falta de disposição, em virtude da saúde fragilizada, refletem a imagem do abandono e da solidão. A entrevista transcorreu de forma dramática, na qual os relatos eram transbordados de inconformidade com o falecimento do marido e a ausência da única filha que mora em outro município, afirmando e reafirmando que o que a mantém viva é a fé, a religião.

Ao falar sobre os três netos, sua expressão transforma-se, sua fala flui com mais firmeza. Diz que não conta nada aos seus netos, mas logo reconhece que seus conselhos foram ouvidos por um dos netos na definição de projeto profissional e vocacional, pois situa a sua maior felicidade na escolha do neto mais moço de formar-se em teologia seguindo a carreira de pastor. Pode-se pensar que a religião luterana é para Hermine, a razão da manutenção de sentido na sua vida, algo que sempre esteve presente e que hoje a faz prosseguir. Ao definir seu futuro escolhendo ser pastor, o neto de Hermine traçou uma convergência de interesses em uma escala semelhante àquela que sua avó adotou ao longo da sua vida.

Já o sentimento de abandono e o distanciamento, que costumam ser apontados como características modernas de relações intergeracionais, são enunciados por Eduard como uma situação conflitiva vivida na relação com sua neta. Ao narrar essa situação, ele remete à relação que manteve com seu pai como forma de justificar os ressentimentos: "Eu tento contar histórias para a minha neta, mas às vezes ela nem gosta mais de ouvir. Você sabe como é hoje em dia... Ah! Aquilo eu já sei, não quero saber. É como se diz nos tempos modernos. Os jovens do interior [zona rural] ainda sim, mas a maioria da cidade não quer ouvir o avô ou a avó falar. E eles gostam tanto de falar. Começam a falar e a gente vai embora, não dá bola. Depois eles vão embora, né? Eu também podia ter perguntado muito mais coisa pro meu pai, mas a gente não faz, depois não estão mais ai e a gente sente falta. Antigamente o pessoal não tinha essa folga, 
esse tempo de conversar, tinha que trabalhar e de noite tava cansado. Mas algumas vezes a amizade era muito mais com vizinhos. Mas isso não existe mais, não existe mais. Existe televisão, tomou conta [ . . . ]." (informação verbal).

A modernidade e todo o aparato que daí decorre são apontados como um dos fatores responsáveis pela falta de diálogo. Entretanto, Eduard é reconhecido pela comunidade de idosos como uma pessoa muito habilidosa em contar histórias. Ele coordena um grupo de terceira idade e sua participação intensa é elogiada por outros informantes, principalmente pela arte de contar histórias.

Tais relatos apontam para os paradoxos da vida moderna e da negociação cotidiana entre distanciamentos e aproximações que marcam as relações sociais.

Ao conviver com a comunidade teutoniense, inúmeros exemplos da importância que os avós atribuem aos seus lares puderam ser observados. $\mathrm{O}$ processo de urbanização e de globalização dos tempos atuais tratou de afastar as gerações mais jovens, que saíram em busca de novas oportunidades. Contudo, ainda que os filhos incentivem a transferência dos pais (avós) para outras localidades, acompanhando-os e aos netos, a opção em geral é pela permanência no local, no caso Teutônia, em que a identificação com o passado abranda a constante ameaça de desintegração da identidade dessa geração de idosos. A opção em permanecer em Teutônia, não acompanhando a trajetória geográfica dos filhos para novas localidades, não se faz sem uma carga de sofrimento, como denota o depoimento de Gustav: "A filha depois que se aposentou, resolveu ir para Porto Alegre onde seus filhos estavam estudando. Resolveu montar negócio lá. Ela queria que nós também fosse, mas como se pode deixar a vida da gente que tá aqui, né? Então, agora, nós convivemos pouco, eles trabalham muito. Quando a gente se encontra, eu não tenho muito o que contar, eles já sabem muito. Mas para a filha a gente conta o que viveu aqui, ela sabe tudo, mas os netos não entende mais assim. " (informação verbal).

Os relatos de Gustav e sua esposa assinalaram a ambigüidade entre optar pela permanência na cidade de interior que os abriga e acomoda suas lembranças e a sensação de abandono pela mudança geográfica dos filhos, reduzindo os contatos aos finais de semana, feriados e por comunicação telefônica. 
É importante sublinhar a importância das mudanças tecnológicas, que, à medida que se impõem sobre as vidas das pessoas, influenciam a maneira de elas enxergarem o mundo social. Vê-se claramente que, enquanto os avós eram crianças, não existia a possibilidade de agirem de forma diferente daquela que havia sido determinada por seus pais - como exemplo, a divisão de tarefas diárias realizadas na unidade doméstica: ir à roça, tirar o leite, alimentar os animais etc. Hábitos de um estilo de vida rural que dizem não ser mais de interesse dos seus descendentes, e, assim, encontram dificuldade de transmitir essa herança. Já os netos, dirão sistematicamente, têm muitas possibilidades de escolha, de opções de projetos mais urbanos que divergem do estilo do viver no meio rural, mesmo que hoje a situação rural não seja tradicional: as propriedades rurais localizam-se nas proximidades da cidade, rur-urbana, como comumente vem sendo denominada essa situação.

\section{As Histórias Narradas Pelos Rastros}

Ao longo do percurso da pesquisa, foi tecida a preeminência de dar conta das relações das trocas sociais em que a memória individual e a memória coletiva são estabelecidas em uma memória vivida em círculos mais amplos, cujas narrativas devem ser interpretadas sob a idéia de narrativa construída sobre a problematização do tempo: pré-figuração, configuração e reconfiguração, referindo-se à noção de memória compartilhada proposta por Ricoeur (2000).

Sugeriu-se a noção de rastro como apropriada para refletir sobre os avós que acreditam que nada narram aos seus netos, ou pouco narram, mas transmitem, pelos rastros do convívio e pelas sociabilidades diversas, muitos hábitos que se tornam efetivamente coletivos quando são conformados pela transmissão, uma vez que são perpetuados no contexto familiar e inseridos na ordem maior que é o da comunidade local. Ainda que em tempos de globalização, de indefinição de espaços, haja a emergência de signos de pertencimento bastante claros, por trás dessa emergência há o reconhecimento de que, embora exista uma efetiva ampliação de horizontes em virtude dos processos advindos da globalização, há um maior apego a determinados signos que trazem sentimentos de similitude, de pertença a um local ou a um grupo social. Nesse sentido, pode-se reconhecer o papel dos avós quando transmitem ensinamentos práticos, ou mantêm expostos objetos significativos para seus netos, ou ainda, quando remetem valores por meio de 
comportamentos e silêncios. Esse papel está descentralizado de autoridade, mas recentralizado pelo afeto.

É uma memória alimentada no sentido longitudinal (dos próximos), atravessada por inúmeras transversalidades (grupos de canto, de terceira idade, de bolão), todas também com seus percursos longitudinais, o que Ricoeur chama de vertente simbólica:

[ . . . ] Essa representação de uma humanidade imortal [ . . . ] é o sintoma mesmo de um funcionamento simbólico mais profundo, em virtude do qual visamos a um Outro mais do que humano, cuja carência preenchemos com a figura dos ancestrais, ícone do imemorial, e com a dos sucessores, ícone da esperança. É esse funcionamento simbólico que a noção de rastro vai esclarecer" (RICOEUR, 1997, p.195).

O rastro também é um dos instrumentos pelos quais a narrativa histórica refigura o tempo, indicando uma passagem, não necessariamente uma presença. Ele significa sem fazer aparecer, deixa uma marca no presente em consonância com o acontecimento passado. É o conector de tempos, é um tempo híbrido.

Nesse sentido, os avós que relatam que nada têm a contar a seus netos, pois eles já sabem tudo, ou que eles não querem ouvir por falta de tempo, ou pela presença da televisão, etc., acabam por evocar, em seus depoimentos, conteúdos transmitidos, experiências narradas, hábitos compartilhados.

Ao ouvir as histórias de suas vidas ou em oportunidades de interação entre avós e netos, rastros foram percebidos, traços identitários comuns foram reconhecidos. Investigou-se, então, esses momentos-espaço de interação reinventada, recriada cotidianamente e que é reinventada, justamente, a partir de vínculos com o passado que contribuíram para a manutenção e a preservação de signos comuns, constituidores de uma identidade étnica.

Reconhece-se, em tantas outras situações, que a relação entre avós e netos mantém-se sobre laços estreitos de afeto, em que os restritos momentos de interação tornam-se intensos momentos de troca e de experiências vividas em comum.

As experiências do cotidiano apresentam-se bastante direcionadas ao eu e à identidade social. No entanto, gradativamente, passam a ser 
envolvidas pela multiplicidade de mudanças e adaptações na vida cotidiana sob as exigências de um novo tempo.

Essa foi, sem dúvida, a premissa adotada pelos entrevistados ao refletirem sobre a comunidade local. Todavia, a noção de tradição pressupõe a idéia de persistência e continuidade, de resistência à mudança. Pode-se pensar, a partir dessa questão, que a tradição tem no seu interior um caráter normativo que oportuniza o caráter de vinculação. Nem sempre a tradição é enunciada, como se pode perceber no relato dos avós, porém suas bases afetivas, manifestadas de inúmeras formas, influenciam concretamente o tempo presente seus e de seus netos. A reprodução do passado e a transformação do presente reinventam o cotidiano, recriam pontos de referência coletivos em um tempo reordenado que almeja a continuidade.

A experiência vivida não é transmitida como um acontecimento que ocorre na ordem do privado, é a sua significação que dá sentido e torna-a pública.

À luz do pensamento de Ricoeur (1997) acerca do rastro, a decoração da sala de estar e da cozinha de Elisabeth é rica em sentido. Ambiência povoada de inúmeros quadrinhos bordados ou pintados com as seguintes mensagens escritas em alemão: "Isso eu aprendi da minha mãe", "Homem, ame a natureza para a criatura poder sobreviver", "A fidelidade da mãe renova todos os dias", "Quando tem amor na casa, a bênção de Deus está presente”, "A preguiça retribui com pobreza”, "Olá, entre e traga a felicidade para dentro de casa", "Onde não há paz na casa, a aparência é triste", "O inimigo entra e Deus não gosta de estar", "Aqui você está guardado, você está em casa", "Cozinhe e salgue com moderação, cuide de cada pozinho que tem em casa", "Reze e trabalhe".

Outro exemplo que ilustra a noção de rastro é a sala de Anna, repleta de almofadas e toalhas de mesa elaborados em crochê por ela, pela filha e pela neta. Ou ainda, durante a entrevista foram servidos um cafezinho com uma cuca, feita pela neta e ensinada por Anna.

Ao entrar no quarto de Anna, as inúmeras fotografias da família, a Bíblia no criado-mudo e a estante com livros escritos em alemão são objetos que estão depositados em espaços determinados e que têm a função de elos que a prendem a seu grupo de pertencimento.

Da mesma forma, Frieda conserva fotografias como um ato do retorno em comunhão com a idéia de reviver, pelas imagens, parte de um tempo vivido que confere sentido ao presente. 
Com pequenos gestos cotidianos, singulares mensagens em alemão, em dialeto, em português com sotaque, os avós narram seus saberes, suas lembranças, seus conhecimentos, sua arte. Enfim, os rastros também contam histórias, também têm o papel de transmissão de experiências almejando eternizá-las no tempo.

Dessa forma, os netos compartilham do tempo vivido com os avós quando, conforme assinala Halbwachs (1990, p. 66), eles “[ . . . ] penetram numa região diferente e que, no entanto, não lhe é estranha”. É essa proximidade, ao torná-los semelhantes na diferença, que os torna cúmplices na reinvenção e na renovação do tempo que agora vivem e que hoje é porvir.

A relação entre avós e netos etnografada em Teutônia é fortemente marcada por relações de afeto que suavizam as dificuldades provocadas pelo confronto geracional que estabelece a diferença.

Não são apenas as palavras que definem a co-educação. Os netos e filhos aprendem igualmente nos gestos, nas expressões, nos hábitos de toda ordem (alimentares, musical, forma de se vestir, religiosos) e nos comportamentos codificados e novos.

Sem dúvida, a importância dos diálogos está na preservação e na renovação da oralidade, que resulta, incondicionalmente, no estreitamento dos laços entre diferentes gerações nessa localidade interiorana.

Pensar na arte de contar situada na descoberta do passado vivido pela interpretação da memória dos ancestrais é reduzi-la a uma pequena parte da multiplicidade de acepções definidoras das narrativas que permeiam o interior das relações entre os sujeitos.

As palavras podem ser apreendidas como o pulsar da vida quando, por meio delas, percebe-se o modo pelo qual os sujeitos criam e recriam práticas e pensamentos. Ao analisar as palavras que os avós dirigem a seus netos, reconhecem-se os desafios envolvidos na combinação de tradição e mudança em que se busca a reconstituição mútua de sujeitos a partir de uma convivência afetiva. É um processo de educação transgeracional, que implica a tarefa de convergir em busca de valores que remetem a relações igualitárias, aceitando as diferenças pois, é por meio delas, que se renovam as possibilidades de modificação recíproca dos sujeitos. Ou seja, ao perceber o outro como diferente pode-se enxergar as possibilidades que o outro sugere para a mudança. 


\section{Memória, Valores, Transmissão}

Os dados etnográficos foram analisados a partir dos conceitos de memória e tradição. Recorreu-se a Halbwachs (1990) para analisar a transmissão da tradição, uma vez que, segundo ele, a afetividade é dada nos laços sociais e a partir da relação entre gerações, mais privilegiadamente na figura do avô/avó, narradores em potencial da história e trajetória de seu grupo no papel de guardiões da memória coletiva. Ou seja, está na ligação transgeracional a forma de transmitir a história apreendida e a memória vivida no cotidiano dos sujeitos sociais.

Para Halbwachs, como bem mostra Ricoeur (2000), a familiarização com a memória vivida é, sobretudo, uma experiência intrageracional, isto é, uma experiência vivida transmitida de geração para geração. Essa familiarização, ou um sentimento de pertença, segundo o autor, consiste em um percurso iniciático pelos círculos concêntricos que são o meio familiar, as camaradagens, as amizades, as relações sociais de parentesco e a descoberta do passado histórico pela interpretação da memória dos ancestrais. Ricoeur problematiza esse fenômeno de transmissão de avós para netos, de pais para filhos, assim como da memória transgeracional:

Trata-se de uma experiência forte, que contribui a alargar o círculo dos próximos, abrindo-o em direção a um passado, que, em pertencendo aos nossos ascendentes ainda em vida, nos coloca em comunicação com as experiências de uma outra geração que não é a nossa [... ] A noção de geração aqui é chave e oferece este duplo sentido, o de contemporaneidade de uma mesma geração, à qual pertence o conjunto de seres de diferentes idades, e de seqüência de gerações, no sentido de substituição de uma geração por uma outra $[\ldots]$ conhecemos bem este triplo reino de predecessores, de contemporâneos e de sucessores. (RICOEUR, 2000, p. 514).

Sugere, desta forma, que a relação transgeracional é fonte de comunicação recíproca de experiências e de recomposição da memória vivenciada coletivamente, dinamizando formas de sociabilidade e espaços de interação que falam de um grupo de identidade em que a tradição é reinventada 
em um cotidiano reelaborado no âmbito do processo de modernização e urbanização local, estadual e nacional.

Adotou-se a noção de tradição a partir de Ricoeur (1997) quando denomina "situações de tradição" como tradicionalidade, em que a distância temporal que nos separa do passado é um intervalo de transmissão geradora de sentido: "Antes de ser um depósito inerte, a tradição é uma operação que só se compreende dialeticamente no intercâmbio entre o passado interpretado e o presente interpretante". Ou ainda:

\begin{abstract}
A noção de tradição, tomada no sentido das tradições, significa que nunca estamos numa posição absoluta de inovadores, mas sempre, inicialmente, numa situação relativa de herdeiros. Essa condição está, essencialmente, ligada à estrutura de 'linguagem' da comunicação em geral e de transmissão dos conteúdos passados em particular. (RICOEUR, 1997, p. 379).
\end{abstract}

A partir da interpretação das narrativas, buscou-se desvendar em que sentido a relação entre avós e netos socializa as próximas gerações, em especial os netos, na memória coletiva do grupo (HALBWACHS, 1990) e na experiência temporal vivida (BENJAMIN, 1993) em um contexto teutobrasileiro.

A importância do papel do narrador, identificada nos avós na cidade de Teutônia, estimula a recorrer a Benjamin quando afirma:

O narrador retira da experiência o que ele conta: sua
própria experiência ou a relatada pelos outros. E incorpora
as coisas narradas à experiência de seus ouvintes. Contar
histórias sempre foi a arte de contá-las de novo, e ela se
perde quando as histórias não são mais conservadas.
Ela se perde porque ninguém mais fia ou tece enquanto
ouve a história. (BENJAMIN, 1993, p. 200-201).

Mais ainda, trata-se de dar conta das trocas sociais em que essa memória é vivida no círculo familiar, mas igualmente relacionada a círculos mais amplos. Ou seja, o estudo da narrativa dá conta não só das relações entre os próximos - aqueles do convívio familiar, parental, ou de amigos, mas também das redes mais amplas - grupos sociais outros de referência, como os movimentos de uma geração (feminismo, luta de classes, etc.), os meios 
de comunicação de massa (televisão, radio, etc.) e as políticas econômicas de instituições regionais, nacionais e internacionais. Dessa forma, pode-se falar de uma memória compartilhada baseada nas relações que alimentam os sentimentos de pertencimento (grupo de baile, grupo de igreja, grupo político, grupo de vizinhança, etc.), em grupos considerados distantes e diferenciados, mas compartilhados em suas mudanças na conjuntura histórica.

Entende-se, então, que a transmissão da tradição perpassa a identidade do grupo local, reelaborada cotidianamente no contexto históricosocial a que está sujeita a comunidade teutoniense e no contexto políticoeconômico da sociedade abrangente que se configura em um processo de modernização.

Este estudo antropológico buscou compreender de que forma uma comunidade de origem germânica constrói sua identidade social tendo na etnia, a memória, a família e a religião, entre outros, como seu sistema de valores ("ideo-logia" para Dumont, 1985) ${ }^{11}$ no jogo narrativo de pensar-se como grupo de identidade. (SOARES, 1981).

O estudo interpretativo dos dados etnográficos da relação entre gerações é revelador das referências identitárias a partir das quais os sujeitos pesquisados concebem sentido às suas trajetórias e ao sentimento de pertencimento étnico. Assim, a questão da identidade implica estudar as trajetórias familiares a partir do ponto de vista da geração dos avós, considerando:

\footnotetext{
Os avós ocupam uma posição peculiar frente à coexistência de valores diferentes no domínio familiar. Suas impressões e depoimentos trazem a visão diacrônica de uma realidade que, mesmo não necessariamente elaborada com preocupações sociológicas, representa uma possibilidade de pensar um caminho de mudanças sociais concernentes a um campo social mais amplo do que aquele de sua própria família. A passagem por vários momentos do ciclo de desenvolvimento do grupo doméstico, a idade e a experiência constituem dados concretos que servem, no presente, para a elaboração de discursos sobre sua posição na família, bem como sobre a mudança e a permanência de determinados valores familiares. (LINS DE BARROS, 1987, p. 11).
}

\footnotetext{
${ }^{11}$ Para Dumont, a sociedade ocidental moderna é a única que dissocia fatos e valores e, nessa sociedade, se constata um paradoxo: no plano de sua "ideo-logia", a Parte (indivíduo erigido em valor axial) engloba o Todo (a sociedade como totalidade), fundando o que Dumont denomina ideologia anti-sociológica.
} 
Isto é, a geração mais velha, ao restaurar as suas experiências, está traduzindo suas referências individuais e coletivas de um tempo passado na perspectiva de um tempo presente, de um tempo do momento narrado. $\mathrm{Ou}$ seja, ao narrarem suas experiências, a sua vida, os avós buscam " $[\ldots]$ a lembrança dos acontecimentos que os criaram nos instantes decisivos dos seus passados" (BACHELARD, 1994, p. 39) e, ao contá-las aos seus netos, constroem o espaço-tempo em que "[ ... ] o passado é revivido a partir de um encadeamento afetivo necessariamente presente." (ECKERT; ROCHA, 2001, p. 35).

A análise das narrativas seguiu a noção de memória compartilhada, apoiada na perspectiva de Ricoeur (2000), cuja intriga narrada revela os novos sentidos produzidos a partir da tensão entre o mundo da obra e o mundo do "produtor" (de sentido). A reconfiguração do texto narrado propõe a criação de novos universos como fruto da possibilidade de desconstrução, de fragmentos de vida transformados em fala.

Partiu-se da idéia de família proposta por Lins de Barros, quando diz:

\begin{abstract}
A família pode ser vista como um grupo de pessoas que, unidas pelos laços de parentesco e de afinidade, estabelecem entre si códigos próprios capazes de fazer fluir inúmeras facetas de relacionamentos. A comunhão de uma linguagem reafirma a presença de uma história não só de laços de sangue, mas de laços morais (de socialização), que diz respeito a todos os elementos do grupo. Através dessa história, são alinhavados os laços de parentesco, ao mesmo tempo em que se delineia uma unidade moral familiar. (LINS DE BARROS, 1987, p. 12).
\end{abstract}

Cabe ressaltar a importância, para esta análise, dos estudos de Lins de Barros sobre a relação geracional, estruturados a partir do conceito de representação coletiva, que discute a relação entre o indivíduo e a sociedade. Esse conceito parte de duas vertentes teóricas: o trabalho de Mauss ${ }^{12}$ (1969

${ }^{13}$ MAUSS, M. Oeuvres: cohésion sociale et division de la sociologie. Paris: Les Editions de Minuit, 1979. Apud Lins de Barros, 1987, p. 18. 
apud LINS DE BARROS, 1987, p. 18) e o de Schutz ${ }^{13}$ (1979 apud LINS DE BARROS, 1987). Para o primeiro, “[ ... ] é através da socialização que são transmitidos aos indivíduos os hábitos e as práticas instituídas juntamente com seus significados sociais." Ou seja, é a natureza social das representações coletivas que diferencia as representações individuais, apesar de essas representações coletivas efetivarem-se nas ações e reações das consciências individuais de um determinado grupo. Para Schutz (1979 apud LINS DE BARROS, 1987, p. 21), apesar de o conhecimento do mundo se originar, em sua maior parte, do social, os indivíduos possuem um espaço de escolha e, portanto, a possibilidade de projetar seus futuros a partir de suas experiências de vida.

Com base na análise do simbólico e dos projetos de vida determinados pelas escolhas dos indivíduos, estuda-se aqui o trabalho da memória no processo de construção do estilo de vida e do ethos alemão na comunidade de Teutônia como resultado da relação geracional.

A análise partiu, inicialmente, da identidade étnica elaborada pelo grupo investigado e fundamentou-se nas definições usadas por Seyferth:

\begin{abstract}
A comunidade étnica teuto-brasileira foi definida objetivamente por seus membros a partir do uso cotidiano da língua alemã, da preservação de usos e costumes alemães (incluindo, entre outras coisas, hábitos alimentares, organização de espaço doméstico, formas de sociabilidade, comportamento religioso, etc.) e da intensidade da vida social expressa pelas muitas associações que assumiram forte caráter étnico (como sociedades de tiro, de ginástica, de canto, escolares, de auxílio mútuo). (SEYFERTH, 1994, p. 15).
\end{abstract}

A identidade étnica está ancorada na idéia de descendência comum, que abrange um modo de vida específico e um comportamento cultural diferenciado. No caso da comunidade pesquisada, o "valor englobante" (DUMONT, 1985, p. 259) está associado à descendência alemã, em que características culturais e sociais importantes constituem elementos de diferenciação inclusivos, como a língua alemã. Nesse sentido, a etnia pode ser apreendida como uma “identidade-valor" nos termos de Duarte (1986, p. 130), que “[ . . . ] se confundiria com a própria idéia da 'cultura' como

${ }^{12}$ SCHULTZ, A. Fenomenologia e Relações Sociais. Rio de Janeiro: Zahar, 1979. Apud Lins de Barros, 1987, p. 21. 
'sistema simbólico' e da 'sociedade' como atualização de uma ordem principal abstrata".

Ao tratar da relação geracional, convém pontuar o avô como um sujeito que vive a sua última etapa da vida (LINS DE BARROS, 1987, p.32), o que não significa vivê-la aguardando a morte; nela pode estar inserido um "projeto de velhice". Compreende-se a geração "mais velha" como aquela que mantém um projeto de continuidade ao transmitir suas lembranças e reminiscências.

Partiu-se da idéia de velhice proposta por Bosi (1979), em que ela pode ser concebida como um papel dramático frente a restrições de papéis sociais, mas também como um período de paz, repouso, reconhecimento e expectativas voltadas ao plano afetivo.

Buscou-se reconhecer, pelas narrativas das trajetórias de vida, as categorias sociais estruturadas para, então, compreender a moldura social (HALBWACHS, 1990) e o quadro de referência que se relacionam às memórias evocadas. As reminiscências em indivíduos idosos apresentaramse inesgotáveis e, a cada encontro, novos fenômenos de um passado lembrado, centrados nas vivências familiares, do trabalho, etc., são narrados de maneira simbólica como elemento referencial.

Ao transmitirem (HALBWACHS, 1990) e compartilharem (RICOEUR, 2000) todo um universo de representações e significados, as gerações mais velhas trazem à memória, atualizada na lembrança, a ligação entre eles (indivíduos) e seu mundo, disposta na interface entre o sujeito e o social. Ao traduzir as lembranças em linguagem, essas vêm ao presente ressemantizando o passado, que é evocado a partir das instâncias mais significativas na construção dos seus papéis sociais. Nesse sentido, as vivências familiares apresentaram-se mais enfatizadas nos relatos femininos, enquanto o trabalho e a família surgiram nos relatos masculinos como encompassadores das vivências do passado. Esses elementos referenciais traduzem a vida cotidiana desses sujeitos, marcando, nas suas trajetórias, diferenças de papéis sociais. São o eixo em torno da qual se articulam as representações sobre o cotidiano no passado, revelada nos pequenos atos, gestos, atitudes, rotinas, táticas, estratégias, transmitindo saberes que dão ao cotidiano reinventado, um sentido de continuidade e duração. 


\section{Conclusão}

Por meio da experiência adquirida na convivência com a comunidade teutoniense no processo de pesquisa de campo antropológico, buscou-se apreender nas representações dos habitantes idosos em Teutônia, os significados culturais atribuídos por eles à sua trajetória como descendentes de imigrantes enraizando-se num novo país. Situação que produz diferenciações advindas da intersecção das culturas. A partir de uma etnografia da memória desta duração, enfocou-se a narrativa das experiências vivenciadas a partir de uma relação de reciprocidade entre avós e netos. Nesta perspectiva, buscou-se investigar o cotidiano prático e simbólico vivido e compartilhado pelos sujeitos que estão em contínuo processo de reconstituição e renovação dos seus valores culturais por intermédio da troca de experiências.

A representação dos diversos tempos ordenados na memória revelada nas reminiscências dos avós relaciona a fundação da cidade às trajetórias de vida embalada pelo valor trabalho e solidariedade do grupo, constitutivo tanto de uma lógica do progresso e sucesso econômico, quanto de referências de identidade do grupo de pertencimento etnografado, como uma comunidade teutoniense. Estes valores são, para eles, remetidos à prática de uma tradição transmitida no tempo, como o uso dos dialetos trazidos por seus ancestrais, a religiosidade e a vida familiar, conformadores da ordenação do mundo social. Ou seja, o processo de construção social da identidade teuto-brasileira tem, nesses aspectos enunciados, o fortalecimento do sentimento de pertença marcado decisivamente nas trajetórias desses indivíduos e de seus descendentes, em que as representações do passado articulam-se justificando o presente.

Ao ouvir as histórias de vida, no conjunto de recordações percebese o modo como o mundo cotidiano é negociado pela comunidade, em que o passado é ordenado segundo os significados da vida no presente.

Detentores de uma condição formativa de colonos que vivem ou viveram grande parte de sua vida no meio rural, definida no uso cotidiano da língua alemã, hábitos alimentares, organização de espaços domésticos, formas de sociabilidade e comportamento religioso, os avós vivem em constantes negociações que são reveladoras dessa etnicidade explícita nas características apontadas, bem como são reveladoras do quanto a interação com as gerações dos filhos e netos recria um novo sistema de significações dinamizado na 
transmissão e socialização da memória compartilhada sobre um tempo passado e um presente vivido. Essa memória compartilhada atua simultaneamente nas interações cotidianas da família, nas relações de vizinhança e em outros processos de sociabilidade.

Observou-se, então, que a estreita relação com novos valores citadinos - adquiridos seja nas relações interpessoais, seja nos novos signos da modernidade, como a televisão, o rádio e outros - trouxe à comunidade teutoniense novos ritmos à tradicional convivência familiar e comunal. Isto é, a aquisição de novos traços identitários atualizou a comunidade de pertencimento, as redes, a ancestralidade, as fronteiras culturais que se alargaram, o ethos alemão que se hibridizou e a incorporação das contradições do mundo moderno que se estabeleceu na adoção de projetos pessoais em concordância com projetos familiares, em que são almejadas trajetórias de ascensão social com a conquista de diploma universitário ou de emprego que remeta a uma estabilidade.

Nesse novo contexto, a expressão religiosa adquire contornos e práticas menos rígidas, grupos de terceira idade no município, vistos como o redimensionamento das novas definições de envelhecimento, com uma alteração significativa de geração restrita à família. Esse espaço de sociabilidade revelador de novos sentidos conquistados pela modernidade é visto como uma experiência extrafamiliar, em que a interação entre os participantes estabelece as mudanças na experiência coletiva e no comportamento e a construção de uma tradição ressignificada.

As relações intergeracionais são marcadas pela negociação cotidiana entre distanciamentos e aproximações, onde se vê a transmissão das tradições vividas de forma diferenciada, reordenada por meio de rastros.

A noção de rastros denota outras formas de transmissão de uma tradição. Através deles, os hábitos tornam-se efetivamente coletivos, perpetuados no contexto familiar e inseridos num contexto maior, que é o da comunidade local. Reconhece-se a existência de uma memória compartilhada pela transmissão de ensinamentos práticos, pela permanência de objetos que compõem uma ambiência significativamente comum, ou ainda, pela manutenção de comportamentos fundados em valores herdados dos ancestrais.

A relação intrageracional é revelada numa memória compartilhada quando avós e netos encontram, ancorados nas bases afetivas que os unem, traços de referência coletivos num tempo reordenado que acena à continuidade. 
É na conversão das formas de transmissão que se reconhece a recriação de práticas e pensamentos. A conexão de significados implícitos torna avós e netos sujeitos próximos e cúmplices na reinvenção e renovação do tempo, em que as experiências compartilhadas no cotidiano são fundadas na autoridade do afeto - ele é o elemento que ordena a relação entre as duas gerações.

\title{
THE INTRAGENERATIONAL AND SHARED MEMORY ABOUT TRANSMITTED EXPERIENCES BETWEEN GRANDPARENTS AND GRANDSONS IN TEUTÔNIA (RS).
}

\begin{abstract}
This is an anthropologic study about intergeneration and shared memory that was conducted in the city of Teutonia. It encompasses an ethnographic research (2000-2001) done with older natives, descendents of German immigrants, who colonized that region which today is a prosper city situated in the Vale do Taquari in the Brazilian state of Rio Grande do Sul. The work investigates, through biographic narrations, the traditions of everyday life transmitted from generation to generation, in which grandparents socialize their children and grandchildren in the traditions of their German roots as well as restructure these values in the present days by adapting them to new sociocultural conditions brought about by modernization.

Keywords: Memory. City. Ethnic. Generations. Narrations. Community teutobrazilian.
\end{abstract}

\section{REFERÊNCIAS}

BACHELARD, G. A Dialética da Duração. São Paulo: Ática, 1994. 
BENJAMIN, W. O Narrador: considerações sobre a obra de Nikolai Leskov. In:_. Magia e Técnica, Arte e Política: ensaios sobre Literatura e História da Cultura. São Paulo: Brasiliense, 1993. P. 197-221. (Obras escolhidas, v. 1)

. Sobre Alguns Temas em Baudelaire. In: Charles Baudelaire Um Lírico no Auge do Capitalismo. São Paulo: Brasiliense, 1994. P. 103150. (Obras escolhidas, v. 3).

BOSI, E. Memória e Sociedade: lembrança de velhos. São Paulo: Companhia das Letras, 1979.

BOURDIEU, P. Classe sociale et classe de trajectoires. La distinction: critique sociale du jugement. Paris: Les Editions de Minuit, 1979. P. 122126. (Le sens commun).

DUARTE, L. F. D. Da Vida Nervosa das Classes Trabalhadoras Urbanas. Rio de Janeiro: Jorge Zahar, 1986.

DUMONT, L. Essais sur l'individualisme. Paris: Editions du Seuill, 1985.

ECKERT, C. Memória e Identidade: ritmos e ressonâncias da duração de uma comunidade de trabalho: mineiros de carvão (La grand-Combe, França). Cadernos de Antropologia, Porto Alegre, n. 11, p. 1-84, 1993.

ECKERT, C.; ROCHA, A. L. C. Imagens do Tempo nos Meandros da Memória. In: KOURY, M. (Org.). Imagem e Memória: ensaios em Antropologia Visual. Rio de Janeiro: Garamond, 2001. P. 19-39.

FERREIRA, M. L. M. Memória e Velhice: do lugar da lembrança. In: LINS DE BARROS, M. (Org.). Velhice ou Terceira Idade?: estudos antropológicos sobre identidade, memória e política. Rio de Janeiro: FGV, 2000. P. 207-222. 
HALBWACHS, M. Memória Coletiva. São Paulo: Revista dos Tribunais, 1990.

LANG, G. Colônia Teutônia: história e crônica: 1898-1908. Novo Hamburgo: Sinodal, 1995.

LINS DE BARROS, M. M. Autoridade e Afeto: avós, filhos e netos na família brasileira. Rio de Janeiro: Jorge Zahar, 1987.

RICOEUR, P. La Mémoire, L'histoire, L'oubli. Paris: Seuill, 2000. Tempo e Narrativa. São Paulo: Papirus, 1997. 3 v.

SEYFERTH, G. A Identidade Teuto-brasileira numa Perspectiva Histórica. In: MAUCH, C.; VASCONCELOS, N. Os Alemães no Sul do Brasil: cultura, etnicidade, história. Canoas: ULBRA, 1994. P.11-28.

As Identidades dos Imigrantes e o Melting Pot Nacional. Horizontes Antropológicos: Programa de Pós-Graduação em Antropologia Social da UFRGS, Porto Alegre, ano 6, n. 14, p. 143-176, 2000.

SOARES, L. E. Campesinato: ideologia e política. Rio de Janeiro: Jorge Zahar, 1981. 